\title{
MANAGEMENT AND TAXATION IN ENVIRONMENTAL PROJECTS: ECUADOR'S YASUNÍ-ITT INITIATIVE (YASUNÍ ITT TRUST FUND)
}

\author{
Milenka Villca Pozo \\ Professor of Financial and Taxation Law, Faculty of Legal Sciences, URV \\ milenka.villca@urv.cat \\ Malka San Lucas Ceballos \\ Researcher, Centre d'Estudis de Dret Ambiental, URV \\ malka.sanlucas@estudiants.urv.cat
}

Received: March 8th 2015 / Accepted: April 29th 2015

\begin{abstract}
In 2007 the government of Ecuador initiated an ambitious environmental project to prevent the exploitation of the most significant oil reserves in the country located in the Yasuní National Park. To make the project operational an international trust fund was constituted in 2010. The following article will focus mainly on analyzing the legal support that the trust fund has provided in the management and administration of the Yasuní-ITT (Ishpingo, Tambococha, Tiputini) Initiative. With this intention, we examine the objectives and internal structure of the Yasuni ITT Trust Fund, its administration of the international contributions, its monitoring system and its transcendent taxation aspects. This study reveals that during the three years that the Yasuní ITT Trust Fund was in force, it was the instrument for the international implementation of the Initiative, despite its early termination due to the lack of international cooperation and the inconsistencies and contradictions of the Ecuadorian government.
\end{abstract}

RESUMEN: En el año 2007 el gobierno de Ecuador inició un ambicioso proyecto ambiental para evitar la explotación de las reservas petroleras más importantes del país, ubicadas en el Parque Nacional Yasuní, para cuya ejecución en el 2010 se constituyó un 
fideicomiso internacional. Este trabajo tiene como principal objetivo analizar la base legal que la figura del fideicomiso ha brindado en la gestión y administración de la iniciativa ambiental Yasuní-ITT (Ishpingo, Tambococha, Tiputini). Con este propósito, en el estudio se examinan los objetivos y estructura interna del Fideicomiso YasuníITT, la administración fiduciaria de las contribuciones internacionales recaudadas, la fiscalización y los aspectos impositivos de transcendencia del Fideicomiso. El estudio pone de manifiesto que en los tres años de vigencia que tuvo el Fideicomiso YasuníITT, su instrumentación a través de esta figura permitió poner en marcha este proyecto ambiental a nivel internacional, a pesar de que se haya concluido antes de tiempo al no hacerse viable su continuación, principalmente, por la falta de cooperación internacional y debido a las inconsistencias y contradicciones por parte del gobierno ecuatoriano.

RESUM: Al 2007, el govern d'Equador va iniciar un ambiciós projecte ambiental per tal d'evitar l'explotació de les reserves petrolieres més importants del país, situades al Parc Nacional Yasuní, raó pel qual va constituir un fideïcomís internacional al 2010 per a la seva execució. Aquest treball té com a principal objectiu analitzar el suport legal que la figura del fideïcomís ha brindat en la gestió i administració de la iniciativa ambiental Yasuní-ITT (Ishpingo, Tambococha, Tiputini), així com establir la tributació dels fons del Fideïcomís Yasuní-ITT. Amb aquesta finalitat, a l'estudi s'examinen els objectius i l'estructura interna del Fideïcomís Yasuní-ITT, l'administració fiduciària de les contribucions internacionals recaptades, la fiscalització i els aspectes impositius de transcendència del Fideïcomís. L'estudi evidencia que, en els tres anys de vigència que va tenir el Fideïcomís Yasuní la seva instrumentació a través d'aquesta figura ha permès engegar aquest projecte ambiental a nivell internacional, malgrat que es va concloure abans d'hora per no fer-se viable la seva continuació, principalment, per la falta de cooperació internacional i per les inconsistències i contradiccions del govern equatorià.

KEY WORDS: Yasuní-ITT — Trust fund - Conservation trust - Taxes.

PALABRAS CLAVE: Yasuní-ITT — Fideicomiso — Fideicomiso de conservació — Impuestos. 
PARAULES CLAU: Yasuní-ITT — Fideïcomís — Fideïcomís de conservació Impostos.

Summary: I. Introduction. II. The commercial trust in Ecuador. 1. Noteworthy features of trusts. 2. Conservation trusts and their importance. III. The International Yasuní-ITT Trust Fund. 1. Objectives and structure of the Yasuní-ITT Trust Fund. 2. Management and administration. 3. Financial contributions and the Yasuní guarantee certificates (YGCs). 4. Early termination of the Yasuní-ITT Trust Fund. IV. Control, monitoring and taxation. V. Noteworthy aspects of structuring the initiative through the trust fund. VI. Final remarks. VII. References

\section{INTRODUCTION}

It is well-known that climate change is one of the most important threats facing the planet at the present time, which is why various countries have advocated applying national policies to reduce the emission of greenhouse gases (GHG) as much as they can.

In this context in 2007 Ecuador undertook an important environmental initiative for the conservation of Yasuní, which was declared a national park in 1979. The Yasuní National Park is regarded as one of the most bio-diverse places in the world since it hosts thousands of unique species that contribute to the balance of ecosystems. In 1989 it was recognized as a UNESCO Biosphere Reserve.

The Yasuní-ITT Initiative consisted of the conservation and non-exploitation of 846 million oil barrels from the underground reserves of the Ishpingo, Tambococha and Tiputini (ITT) oil fields in the Yasuní National Park. In this way, the emission of 407 million metric tons of $\mathrm{CO}_{2}$ would be avoided. The Initiative involved Ecuador sacrificing the exploitation of these oil reserves so, to compensate, they asked the international community to reimburse them with at least half of the economic resources that the country would have earned if they had gone ahead and exploited the oil. The money reimbursed would be used to implement national development, environmental and social programs.

The Initiative required an international trust fund, known as Yasuní ITT Trust Fund, to be set up. Through this trust fund the country would receive the international contributions that supported Ecuador's decision not to exploit the oil reserves. The trust fund was intended to be operative for a period of 13 years, but for various reasons (see below) it was terminated before the established deadline. 
The aim of this study is to make a legal analysis of trust funds in Ecuador, with special focus on conservation trust funds in general and the Yasuní-ITT trust fund in particular. We will examine its principal legal aspects, the importance of this kind of initiative and the modifications that had to be made to the fund for it to be operative at the international level.

\section{THE COMMERCIAL TRUST IN ECUADOR}

In Ecuadorian positive law, the commercial trust fund is regulated like a banking contract by which a specific goal or purpose is entrusted to a trust and funds management company in the interest of one or more beneficiaries. The trustor or settlor, who can be a natural or legal person, public or private, transfers the property of the assets affected by the trust to a trustee. The trustee is the institution or organization that is legally entitled to operate and is responsible for managing the assets according to the goals and instructions established in favor of the beneficiary or beneficiaries of the trust fund.

Its main characteristics are the following: a) the irrevocable and temporary transfer of the legal property of the assets to the commercial trust fund; the assets are therefore temporarily owned by the trustee and once the purpose has been accomplished and the trust fund terminated the assets are definitively transferred to the beneficiary; b) the creation of an independent patrimony that is only used for the specific purpose of the trust fund (as we will explain below, this is one of the features that makes the trust fund most attractive, since it provides legal certainty; and, c) the conferral of legal personality. As far as this last characteristic is concerned we should point out that Ecuadorian Ley $N^{o} 107$ del Mercado de Valores (LMV) confers legal personality to the commercial trust fund but with certain limitations given the fact that the commercial trust fund is not a civil law or commercial enterprise but just an entity that is capable of exercising rights and contracting obligations through the trustee, who is its legal representative and manager.

\section{Noteworthy features of trusts}

Of all the elements of trusts that could be highlighted we will focus on two of them. to the most important is the element of trust itself, given the fact that trust is the basic 
subjective element for engaging in the contract in the first place. The trustor trusts in the loyalty and professionalism of the trustee and also trusts in the fact that the trustee will carry out the necessary tasks to accomplish the established purpose of the trust, acting according to what has been agreed in the contract and in the legal regulations concerning commercial trusts.

In this regard, as manager of the trust, the trustee has the fundamental duty to act expeditiously and accomplish the entrusted purpose. To this end the trustee must apply the established rules for trusts and the criteria pertinent to the business that is being carried out since all the general parameters related to the management of the trust are not always fully determined in the contract.

The second element that needs to be highlighted is the autonomous nature of the patrimony of the trust, which emerges as a legal effect of the constitution of the trust. This is what has been regarded as the most noteworthy feature of the Latin-American trust. The autonomy granted to the assets transferred to the trust allows them to remain dissociated from the personal patrimony of the trustor, the trustee and the beneficiary. Therefore, these assets are only meant to be used for the purpose of the trust.

For these reasons, this last feature of the trust is its most attractive since it provides the legal certainty that all the subjects involved in the trust seek and value when starting up a business or operation. They know beforehand that if the trust fails, the assets transferred to the trustee as a consequence of the trust will not be included as bankruptcy assets; they will remain separate and can only be levied or subject to precautionary measures when it comes to creditors of the trust itself.

\section{Conservation trusts and their importance}

From a practical point of view the commercial trust is regarded as a highly flexible contractual instrument that can be used for different purposes in such private and public sectors as investment and finance. In the environmental sector conservation trusts are 
commonly used. The process of constituting these trusts is the same as the one used for other kinds of trust. The trustor, a private person or a nongovernmental organization (NGO) working on conservation for example, uses a contract to transfer the property of certain premises that he/she wants to protect and preserve to an independent patrimony that will be managed by a trustee in accordance with the purpose of the trust.

Nowadays this kind of trust is being used in Ecuador to sustainably preserve, protect and manage land, forests and natural resources of major ecological importance. These trusts are gradually acquiring importance in Ecuador since they are being increasingly used by Conservation NGOs and individuals. Their importance is such that they are seriously considered as a flexible and safe legal alternative for preserving and maintaining these areas of ecological significance.

As the manager of the transferred land, the trustee must execute all the tasks to fulfill the purpose of the trust, which is the conservation of the land in accordance with the instructions and clauses of the contract. The trustee must not only observe the obligations and duties established in the law but also the best practices and recommendations enforceable against managers. This is why conservation trusts and ecological easements have become one of the most used legal options for conservation purposes. They are an important resource for supporting a wide variety of environmental projects. One example of this is the Yasuní-ITT Trust Fund.

\section{THE INTERNATIONAL YASUNÍ-ITT TRUST FUND}

\section{Objectives and structure of the Yasuní-ITT Trust Fund}

The Yasuní-ITT Trust Fund was established on 3 August 2010, through the "Memorandum of Agreement for Management and Other Support Services Related to the Ecuador Yasuní ITT Fund" between the Government of Ecuador and the MultiPartner Trust Fund Office (MPTF Office) of the United Nations Development Programme (UNDP).

This fund was set up so that the international community could channel its financial contributions for reducing $\mathrm{CO}_{2}$ emissions, preserving the cultural and biological diversity of the zone, investing in renewable energy sources and reducing poverty in 
Ecuador, all based on the common but differentiated responsibilities principle. The fund was supposed to benefit from the financial support of the international community with the participation of Ecuador, civil society and the a variety of donors. In this regard, the main objective of the Yasuní-ITT Trust Fund was to collect contributions of at least US $\$ 350$ million per year, for a period of 13 years. The total contribution would represent $50 \%$ of what the government would have earned if the oil had been extracted from the ITT reserves And prevents the generation of 407 million $\mathrm{CO}_{2}$ metric tons.

The contributions collected for the Yasuní-ITT Trust Fund were meant to be used to carry out strategic sustainable development programs as part of the Plan Nacional de Desarrollo del Ecuador (Ecuador's National Development Plan), as established in the Memorandum of Agreement, the Terms of Reference (28 July 2010) and any regulations that may subsequently be established.

These programs are specifically designed to:

1. Prevent deforestation and conserve ecosystems, particularly the national system of natural protected areas and its buffer zones. The total surface area currently under State protection approximately amounts to $20 \%$ of Ecuador's territory, one of the highest percentages in the world. Properly conserving the Yasuní National Park would also allow the Tagaeri and Taromenane indigenous peoples to remain in voluntary isolation.

2. Encourage reforestation, afforestation, natural regeneration and appropriate management of one million hectares of forest owned by small and medium landholders that is currently threatened by soil degradation. The programme also aims to substantially reduce the current rate of deforestation, one of the highest in South America, and includes watershed management.

3. Promote the use of renewable energy and increase national energy efficiency and energy savings, including investment in environmentally friendly and socially inclusive renewable energy plants: hydro, geothermal, solar, wind, biomass, and tidal. It also envisages providing financial support for energy efficiency in industry and homes.

4. Promote social development in the Initiative's zones of influence, with programs that include health, education, training, technical assistance and productive job creation in such sustainable activities as ecotourism, agriculture, protection of ecosystem services and agro-forestry. 
5. Support research, science, technology and innovation with programs that enhance: a) the generation of goods and services based on bio-knowledge, $b$ ) integrated river basin management, and c) change in the energy matrix, prioritized in the Ecuadorian National Development Plan.

Structurally, the Yasuní-ITT Trust Fund was divided into two windows, a capital fund window and a revenue fund window. The former was financed by contributions to the Yasuní Fund account and/or by the issuance or sale of Yasuní guarantee certificates (YGCs) to private and/or public entities, and was meant to be used to finance renewable energy projects submitted by recipient organizations. On its part, the Revenue Fund Window was financed with mandatory annual revenue that recipient organizations paid for the right to use the funds from the Capital Fund Window. The revenue fund window was used to fund development projects within the framework of the strategic sustainable development programs described above.

\section{Management and administration}

The Yasuní ITT Trust Fund was administered by the MPTF Office of the UNDP. As trustee the Office managed the trust in accordance with the UNDP regulations and rules established for this kind of trust. The trustee also managed the trust fund in accordance with the Yasuní ITT Trust Fund Terms of Reference and the Memorandum of Agreement signed between Ecuador and the UNDP.

Among other things, the trustee was responsible for:

- Receiving financial resources from contributors and payments from the sale of YGCs and depositing them in the Yasuní Fund account for transfer to the capital fund account.

- Notifying the Government when the financial contributions were received and requesting it to issue YGCs to Contributors within 30 days for the amount contributed;

- Disburse the funds from the capital fund window to each recipient organization for the Yasuní Fund projects in accordance with the decisions of the Yasuní Fund Steering Committee;

- Receiving annual revenue payments from the recipient organizations for the amount approved by the Yasuní Fund Steering Committee from the capital fund 
window for each recipient organization;

- Disburse the funds from the revenue fund window to the implementing organizations, in accordance with the decisions of the Steering Committee and the instruction of the Government's coordinating entity;

- Providing a final report, including notification that the Yasuní Fund has been operationally completed, in accordance with the Yasuní Fund TOR;

- Providing a final report on the Yasuní Fund.

The Yasuní Fund was governed by a steering committee of six full members, each one with a vote (three representatives of the Ecuadorian Government, including the Chairperson with the casting vote; two representatives from the Contributor Governments; and one representative of Ecuadorian civil society) in addition to two ex officio members (UNDP Resident Representative and the Executive Coordinator of the UNDP MDTF Office, representing UNDP as the Administrative Agent).

Among other things the Steering Committee was responsible for:

- Providing overall leadership, setting the strategic direction, overseeing the Yasuní Fund, and reviewing and making fund allocation decisions on all Yasuní Fund activities;

- Authorizing the administrative agent to release funds to the recipient and implementing organizations;

- $\quad$ Reviewing and approving the Yasuní Fund Annual Strategic Plan;

- Reviewing and approving the annual estimated costs submitted by the administrative agent to cover its fund administration services and ensure that payments are made;

— $\quad$ Reviewing and approving the Annual Yasuní Fund Consolidated Report;

- Overseeing the monitoring and evaluation of all Yasuní Fund activities to ensure fund-wide success and transparency and ensure coherence and/or collaboration between the Yasuní Fund and national programs;

- Ensuring coordination with other leading initiatives related to the United Nations Framework Convention on Climate Change (UNFCCC) and other conventions.

As requested by the Ecuadorian government, the MPTF was meant to manage the trust 
until there were no more contributions for an initial operational period of ten years.

\section{Financial contributions and the Yasuní Guarantee Certificates (YGCs)}

By the end of 2012 the total amount collected by the Yasuní-ITT Trust Fund totalled US $\$ 6.5$ million, which had been contributed by a variety of contributors: the governments of Chile, Colombia, Georgia, Italy, Spain and Turkey, the regional governments of Wallonia (Belgium), Meurthe-et-Moselle (France), Rhone-Alpes (France), and Limousin (France), two foundations (Avina and World of Kindness), private companies (Constructora N Odebrecht, Everfresh, MUJI and SK Engineering and Construction) and many private citizens (Héctor Delgado and Nina Chen). The following chart shows the various contributions:

Chart 1. Deposits made by the contributors

\begin{tabular}{|l|c|c|c|}
\hline \multicolumn{1}{|c|}{ Contributor } & Previous years & & \\
& Jan-Dec 2011 & & TOTAL \\
\hline Fundación Avina & 100,000 & & 100,000 \\
\hline Chile & 100,000 & & 100,000 \\
\hline Colombia & 100,000 & & 100,000 \\
\hline $\begin{array}{l}\text { Constructora N } \\
\text { Odebrecht }\end{array}$ & 129,975 & & 129,975 \\
\hline Earth Day Network & 125,000 & 158,853 & 158,853 \\
\hline $\begin{array}{l}\text { Ecuador (contrato de } \\
\text { Servicios de Difusión } \\
\text { Pública) }\end{array}$ & $1,400,400$ & & 250,000 \\
\hline Spain & 20,000 & 30,000 & $1,400,400$ \\
\hline Everfresh (Turkey) & & & 50,000 \\
\hline
\end{tabular}




\begin{tabular}{|c|c|c|c|}
\hline Georgia & 100,000 & & 100,000 \\
\hline Héctor Delgado & 50,000 & & 50,000 \\
\hline Italy & & $1,965,519$ & $1,965,519$ \\
\hline $\begin{array}{l}\text { Meurthe-et-Moselle } \\
\text { (France) }\end{array}$ & 53,763 & & 53,763 \\
\hline Rhône-Alps (France) & 195,314 & & 195.314 \\
\hline $\begin{array}{l}\text { Walloon Region } \\
\text { (Belgium) }\end{array}$ & & $1,220,465$ & $1,220,465$ \\
\hline $\begin{array}{l}\text { Ryohin keikaku Co. } \\
\text { Ltd (Japan) }\end{array}$ & & 200,140 & 200,140 \\
\hline Private sector & 44,847 & 136,884 & 181,731 \\
\hline $\begin{array}{l}\text { SK Engineering \& } \\
\text { Construction }\end{array}$ & & 50,000 & 50,000 \\
\hline Turkey & 100,000 & & 100,000 \\
\hline $\begin{array}{l}\text { World of Kindness } \\
\text { (Russia) }\end{array}$ & 100,000 & 19 & 100,019 \\
\hline Total & $2,619,299$ & $3,886,881$ & $6,506,179$ \\
\hline
\end{tabular}

Source: Drafted by the author with information from the 2012 Annual Report of the Ecuador Yasuní ITT Trust Fund for the period 1 January - 31 December 2012.

The contributors mentioned above received the corresponding YGCs, a financial document issued by the Ecuadorian government as a guarantee that the oil would not be extracted from the ITT for an indefinite period. Only YGCs for the 407 million $\mathrm{CO}_{2}$ metric tons that would not be generated by exploiting the ITT were allowed to be issued. The YGC was an instrument that did not earn interest and did not have an expiry or maturity date as long as the Government respected its commitment not to exploit the Yasuní ITT oil reserves.

Chart 2 provides a detailed list of the amount of YGCs issued by the Ecuadorian government. 
Chart 2. YGCs issued by the Ecuadorian Government

\begin{tabular}{|l|l|}
\hline Contributor & Amount of YGCs \\
\hline Fundación Avina & 100,000 \\
\hline Chile & 100,000 \\
\hline Colombia & 100,000 \\
\hline Constructora N Odebrecht & 129,975 \\
\hline Earth Day Network & 153,041 \\
\hline Spain & $1,400,400$ \\
\hline Everfresh (Turkey) & 20,000 \\
\hline Georgia & 100,000 \\
\hline Gov. of the Walloon Region (Belgium) & $1,220,465$ \\
\hline Héctor Delgado & 50,000 \\
\hline Italy & $1,965,519$ \\
\hline Meurthe-et-Moselle (France) & 53,763 \\
\hline Rhône-Alps (France) & 195,314 \\
\hline Ryohin Keikaku Co. Ltd. (Japan) & 200,000 \\
\hline SK Engineering and Construction & $1,400,400$ \\
\hline Turkey & 100,000 \\
\hline World of Kindness (Russia) & 100,000 \\
\hline Total & $\mathbf{2 , 3 4 9 , 4 5 2}$ \\
\hline
\end{tabular}

Source: 2012 Annual Report of the Ecuador Yasuní ITT Trust Fund for the period 1 January - 31

December 2012

The YGCs were issued for the nominal value of each contribution. The YGCs included the metric tons of $\mathrm{CO}_{2}$ avoided according to the price on the date of issue of the European Union Allowances (EUAs) in the Leipzig Carbon Market.

Besides guaranteeing that the reserves would not be exploited, the government of Ecuador also tried to earn resources for the trust fund by selling the YGCs in the US 
market to see if they would be accepted as equivalent to emission permits. This was never effective since the YGCs did not meet the requirements of the European market allowances, which had been established by the international legal system after the climate change policies initiated by the Kyoto Protocol. Europe only allows the commercialization of emission allowances recognized by the Kyoto Protocol: for example, Emission Reduction Units "ERUs" (generated by the Joint Implementation "JI" flexible mechanism), Certified Emission Reductions "CERs" (generated by the Clean Development Mechanism "CDM"), the Removal Unit "RMU" (related to carbon absorption by land use, land-use change and forestry activities such as reforestation), Assigned Amount Unit "AAU" (issued up to the level of initial "assigned amount" of an Annex 1 Party to the Kyoto Protocol), Temporary Certified Emission Reductions and Long-term Certified Emission Reductions. As a study prepared by Climate Focus demonstrated, YGCs, could not be accepted in the European market of emission rights because they did not fit any of the existing emission rights categories at the time.

So the government of Ecuador used another mechanism to collect money for the Initiative: the debt swap. The debt swap involved cancelling Ecuador's external debt if the country agreed not to exploit the ITT and use the resources generated by the debt waive for the environmental projects included in the Initiative. Through this mechanism the country gained significant contributions from countries like Spain, Colombia, Chile, Georgia, Turkey and Italy.

\section{Early termination of the Yasuní-ITT Trust Fund}

Even though the Yasuní-ITT Initiative had the support of such international institutions as the German Parliament, the European Union, the Andean Community, the Andean Development Corporation and the Organization of American States (OAS), and several countries, it was terminated early by Decree No. 74 of 15 August 2013. Through this Decree the trust fund was also terminated and settled. It was clear from the beginning that the Initiative depended on international and national support. Through it, Ecuador tried to demonstrate its ethical and political concern for the preservation of the Yasuní, the struggle against climate change and compliance with specific national goals such as a service-based and added-value economy and a fairer and more equitable society. 
It could be said that the requirements for the Initiative to work were not met. The results of the trust fund depended mainly on the international contributions. The Yasuní-ITT Initiative undoubtedly proposed a change of paradigm and an opportunity to rethink the economic model based on ecological principles and with a local and global perspective. However, this change was not made and the international contributions were insufficient for the purpose of the trust fund. Therefore, the Initiative was considered to be no longer feasible.

It should be pointed out that the failure of the Initiative was not only due to the lack of international cooperation. As we have stated above there were also inconsistencies and contradictions from the Ecuadorian government, which also affected the feasibility of the project. Although they were promoting the Yasuní-ITT Initiative, the government always had a Plan B; an alternative to exploiting these oil reserves was always on the table. This led to a lack of credibility from the international community.

The existence of a plan B (for oil exploitation) undoubtedly undermined trust in the priority plan, plan A (the Yasuní-ITT initiative). The encouragement of investments and advances in the operations in block 31 and on the border of the ITT, the arrangements with China for the pre-sale of oil in exchange for debt relief, confused national and international public opinion.

We should also take into account that in Ecuador decisions are usually taken so that money keeps flowing into the State's chest and since the State is the one and only owner of the natural resources and is the only one with competence to use them the government proceeded to announce the exploitation of ITT, forgetting its public commitment to protect the environment and diversify the energy matrix.

Still, the termination of the trust fund does not mean that the entire reserves of the ITT will now be exploited. The government has informed that they will exploit only " 0.1 per cent" of the oil in this field, less than 1000 hectares. However, studies carried out by critics of exploitation have concluded that the affected area is bigger than just " 0.1 per cent". This figure only accounts for one variable: the hectares that will be deforested so that the infrastructure can be set up. The critics argue that the exploitation really involves such other variables as the direct and indirect impacts of the exploitation of the Amazon's ecosystem and its peoples. It will affect not only where the infrastructure is installed but also neighboring areas which will suffer noise, habitat losses and the constant risk of an oil spill and the pollution of aquifers, among other thingss. 
We would also like to point out how difficult it is to find an equilibrium between the need to protect indigenous rights and biodiversity as a public good and the need that a State may have for the economic resources provided by extraction. Although this is not the main object of this study, some of the essential aspects of the idea should be mentioned. Because the State is the owner of non-renewable resources, Ecuador's National Assembly declared the exploitation of the ITT to be of national interest, alleging that the economic resources obtained would be used for the common benefit.

However, as well as containing the most important biodiversity in the world the Yasuní National Park is also inhabited by indigenous peoples in voluntary isolation. Therefore, oil extraction in the Yasuní-ITT threatens not only nature but the livelihood and lifestyles of the Tagaeri and Taromenane, which directly contradicts the protection afforded to indigenous groups in the Ecuadorian constitution. So it is not only a question of environmental and production impacts; it is also a question of human rights.

The exploitation of the ITT reserves will result in a net present value of US $\$ 18,292$ million expected for 2017. These funds will be used to address the urgent needs of the poorest sectors in Ecuador, specially the Amazon. Nevertheless, the suggestion that this profit will bring Ecuador out of poverty is a fallacy. The country has been exploiting oil for 41 years and there has been little development and poverty has not been eradicated. And as has been mentioned above, the situation involves not only economics but political ethics because the Ecuadorian constitution establishes human rights and the rights of Nature.

After many years of promoting the Yasuní-ITT Initiative, Ecuador has become an advocate of this kind of project and one of the countries that has taken important decisions against climate change and in favour of protecting biodiversity and indigenous populations. If the Initiative had succeeded at least part of the park would have been protected for the coming years and Ecuador would have become a country where international law's precautionary principle would have been respected. According to their capabilities, states must apply the precautionary principle by adopting effective measures to prevent the degradation of the environment. This principle is also established in the Ecuadorian constitution.

\section{CONTROL, MONITORING AND TAXATION}


The Yasuní-ITT Trust Fund was subject to internal and external control and monitoring. Externally, the Trust Fund was subject to the UNDP's regulations, rules and procedures for managing international trust funds and the Terms of Reference of the Yasuní Trust Fund were also taken into account. According to article 7 of the Memorandum of Agreement, the Administrative Agent would be audited in accordance with its own Financial Regulations and Rules. In consistence with this, article 3.14 of the same document established that the Yasuní Fund Account would be subject exclusively to the internal and external auditing procedures laid down in the UNDP financial regulations, rules, directives and procedures. Consequently, the administrative tasks, the accountancy and the balance of the trust and other actions were monitored in accordance with these provisions.

The accounts, finances, patrimony and legal information of the Government Coordinating Entity of the Trust Fund, and the Recipient and Implementing Organizations were also audited in accordance with the Terms of Reference, the Memorandum of Agreement and the Manual of Procedures for the Steering Committee, and, of course, in accordance with the law, regulations and procedures of the national legislation when applicable.

This duality of auditing procedures meant that the trust fund was subject to continuous external and internal control. They helped to ensure transparency and guarantee that the contributions were properly used. There was a constant exchange of information with the contributors, who were able to consult detailed reports about the use of the resources contributed to the fund.

We should point out that an intense promotional campaign was initiated around the world, especially in Europe, North America, Australia and Asia. The Ecuadorian government negotiated a variety of mechanisms by which contributions could be made. One of these mechanisms was tax exemption so that international contributors would be encouraged to donate and cooperate with the fund. These tax exemptions were established through formal agreements, with different specifications in each case. In the United States for example, an agreement was reached with the tax authorities so that the American contributors could have tax discounts under Agreement 501(c) 3.

We will now go on to discuss the internal taxation aspects of the Yasuní-ITT Trust Fund. As far as the main parties of the contract - the trustor and beneficiary (Ecuador) and the trustee (MPTF) - are concerned, according to national laws and regulations, if 
the country itself is a beneficiary then it is not subject to income tax. According to article 98 of the Ley Orgánica de Régimen Tributario Interno (LORTI), which is the national organic law that regulates all national taxation issues, the term "company or society" refers to the legal person, de facto companies, commercial trust funds, and autonomous or independent patrimonies with legal personality, except those constituted by the State's institutions and these institutions are the beneficiaries. Therefore, the trust fund established by the State is not regarded as a company by the provisions of this law as long as the beneficiary is the State itself or other public institutions.

Hence, since the Yasuní-ITT Fund is not regarded as a company, it is not subject to income tax. However, the income the trustee is entitled to for managing the fund would be taxable under articles 4 and 8 of the LORTI. Even though the trustee is a foreign entity, the payments made to the trustee are from Ecuadorian sources because the trust fund was legally registered in Ecuador, so the legal effects deriving from it are produced in this country and it is the Ecuadorian government that pays the trustee for the service.

It should be pointed out that the Memorandum of Agreement makes no particular reference to these issues. It only states that the government will pay the UNDP before it starts to provide the administration services, and that it will authorize the UNDP through the Steering Committee to debit these amounts from the trust fund's account. It makes no mention of tax payments; it only refers to the obligation of submitting reports. Regarding the transfer of property to the Yasuni-ITT Trust Fund, in accordance with article 536 of the Código Orgánico de Organización Territorial, Autonomía y Descentralización of 11 August 2010, and article 113 of the LMV, this transfer or transaction is tax free. No excise tax, added value tax or business profit tax should be paid.

The Yasuní-ITT Trust Fund generated a variety of fiscal effects because several legal acts were involved. Therefore, the fiscal authorities were forced to analyze each situation individually in order to distinguish and define, case by case, whether taxes were applicable or not. In this regard, the authorities were asked to interpret and clarify various cases. 


\section{NOTEWORTHY ASPECTS OF STRUCTURING THE INITIATIVE THROUGH THE TRUST FUND}

The use of a trust fund to implement and enforce the Initiative has revealed some of the advantages and disadvantages of this legal institution. In the first place, it is a suitable instrument for structuring large-scale projects like the Yasuní-ITT Initiative. It is flexible enough to adapt to the different objectives or legal purposes, which in this case are to mitigate climate change by not exploiting the ITT. It also allows for wide-ranging participation: in this case, Ecuador (the country itself) the MPTF Office, the UNDP, various ministries, companies, NGOs, and local and foreign individuals who decided to get involved in the Initiative.

Second, the independence of the patrimony allows the funds to be used exclusively for the purposes of the trust fund. The contributions cannot be reached by third parties or creditors since they can only be used for liability matters regarding the obligations contracted for the purpose of the Trust Fund. In this way, the Trust Fund serves as a mechanism for channeling the international community's contributions and guaranteeing that they are effectively and exclusively used for the sustainable development programs within the Initiative. It is the independence of the patrimony that provides legal certainty.

Third, the management of the trust fund and its resources is transparent and specialized because the trustee must act in accordance with specific control regulations. The trustee of the Yasuní-ITT Trust Fund was in charge of managing the contributions and disbursing funds to the various organizations, and was obliged to report to the control authorities and the donors. As stated above, this institution had the technical capacity required for the task since it was specialized in managing this kind of fund.

Not surprisingly, many trust funds of this kind have been established in Latin America and in European and Anglo-Saxon countries for the development of environmental projects. The trust has increasingly acquired more importance than other institutions or contracts for carrying out conservation and sustainable development projects in important areas. Some examples are:

- In 2009 the World Bank (WB), together with regional development banks and the Clean Technology Fund (CTF), established a Trust Fund to invest in projects and programs in developing countries to implement and transfer low carbon technologies to 
reduce GHG emissions.

- In 2008 the Norwegian government created the Fondo Amazonía to prevent, monitor and fight deforestation and therefore reduce GHG emissions resulting from deforestation in the Brazilian Amazon.

- In 2006 the Mexican government established the FOMERCAR Trust Fund to support companies and public sector institutions in carrying out CDM projects and other sustainable development initiatives.

\section{FINAL REMARKS}

This study reveals the obvious importance of conservation trust funds in Ecuador. They have increased in number in recent years because they are safe and flexible legal alternatives for preserving forests, land and areas of major ecological significance.

With all the benefits and disadvantages that the Yasuní-ITT Initiative may have for the future for the country, from the global point of view, it constituted a model of social and economic development designed to bring effective solutions to climate change by protecting places that are rich in biodiversity.

Without any doubt, and despite its failure, this Initiative has served to demonstrate to the world that it is possible for a country to reach a higher level of harmonization between economic and environmental interests by limiting the exploitation of natural resources and prioritizing other development models based on knowledge and sustainable development, respecting biodiversity and indigenous populations, and reducing the impacts of climate change. However, this change requires everybody to participate.

In taxation terms, the diversity of the operations involved in the Yasuni-ITT Trust Fund has brought to light the complexity of the legal effects of the trust fund on its participants and third parties. This has forced the national tax authorities to interpret, analyze and define the application or not of the different taxes case by case. It is clear that Ecuadorian legislation sets the basis of the tax regime governing the operations of the trust fund but the dynamics of the trust fund itself make it necessary to interpret specific acts and identify any possible fiscal consequences. 


\section{REFERENCES}

ACOSTA, A., "La Iniciativa Yasuní-ITT. La difícil construcción de la utopía”, in Revista de la Pontificia Universidad Católica del Ecuador (PUCE), no 3.10.2013.

AGUIRRE TORRES, C., Algunos Criterios sobre: Instrumentos Jurídicos de Conservación Privada, Fundación Podocarpus, Ecuador, 2005.

ANDRADE MENDOZA, K., "E1 Parque Nacional Yasuní y la Iniciativa Yasuní-ITT frente a la explotación petrolera. ¿Conservación o Explotación?”, in Krainer A. \& Fernanda Mora M. (coords.), Retos y Amenazas en Yasuní. FLACSO-WCS. Quito, Ecuador. 2011.

ARIAS, V., El fideicomiso de conservación. La experiencia en Ecuador, The Nature Conservancy, Quito, 2006.

AAVV., "Yasuní - ITT: An iniciative to change history", UNDP Ecuador, 2011 p. 51. Consulted 2 March 2015, available at: <Yasuní-itt.gob.ec/download/documentos/7.pdf $>$.

CLIMATE FOCUS, “Análisis legal y financiero de la Implementación de la Iniciativa ITT-Yasuní. Los Certificados de Garantía Yasuní y el Fideicomiso Mercantil de Transformación Energética", drawn up by Deutsche Gesellschaft für Technische Zusammenarbeit, 5 May 2009.

COLECTIVO DE GEOGRAFÍA CRÍTICA DEL ECUADOR. Manifiesto en Defensa del Yasuní (9 April 2014), pp. 4-10. Consulted 2 March 2015, available at: $<$ http://geografiacriticaecuador.wordpress.com/2014/04/11/colectivo-en-defensa-delYasuní/>.

CORRAL A. \& HIDAlgO, R., Guía para la Conservación en Propiedades Privadas, Centro Ecuatoriano de Derecho Ambiental, Quito Ecuador, 2006.

DÍEZ-PICAZO, L., Fundamentos de Derecho Civil Patrimonial, Tomo IV, Aranzadi, Navarra, 2010.

FALCONÍ, E. \& SUÁREZ, S., La Conservación Privada en el Ecuador. Herramientas legales y marco jurídico aplicable, Centro Ecuatoriano de Derecho Ambiental, Quito Ecuador, 2010.

GONZÁLEZ TORRE, R., "Ley del Mercado de Valores: Breve estudio crítico del 
fideicomiso mercantil", in Revista Jurídica, Facultad de Jurisprudencia y Ciencias Sociales y Políticas, volume 8. Consulted 2 March 2015, available at: $<$ http://www.revistajuridicaonline.com>.

— Manual del Fideicomiso en Ecuador y América Latina, Edino, Guayaquil, 2009.

LARREA C. \& WARNARS, L., “Ecuador's Yasuní -ITT Iniciative: Avoiding emissions by keeping petroleum underground", in the journal Energy for Sustainable Development, Vol. 13, no. 3, September 2009.

LÁZARO CALVO T., Derecho internacional del medio ambiente, Atelier, Barcelona, 2005.

MARTÍNEZ E., Yasuní. El tortuoso camino de Kioto a Quito, 1st ed., Abya-Yala, Quito, 2009.

SALAZAR, D., Human Rights and Petro Extraction in the Yasuni, Virtual Dialogues with Latin America. Socio-Environmental Conflicts in Latin America. Lessons from the Yasuní-ITT in Ecuador. Tucson, Arizona, United States of America (Center for Latin American Studies at the University of Arizona. Asuntos del Sur. Flacso - Ecuador), 2014. Consulted 5 May 2015, available at: $<\mathrm{http}$ //las.arizona.edu/sites/las.arizona.edu/files/Yasuni 10 page final $2 \mathrm{mbreal}$ (1).pdf $>$.

SÁNCHEZ CALERO, F., Principios de Derecho Mercantil, 13th ed., Aranzadi, Navarra, 2008.

SÁNCHEZ JURADO, J. A., La Iniciativa Yasuní-Ishpingo-Tambococha-Tiputini y su Impacto en la Economía Ecuatoriana. Quito, Ecuador: FLACSO, Sede Ecuador. Programa de Economía, p. 12. Consulted 15 January 2015, available at: $<$ http://www.flacsoandes.org/dspace/handle/10469/2103>.

SUÁREZ, S., Situación legal de las iniciativas de conservación en los humedales Abras de Mantequilla, La Segua e Isla Santay, Centro Ecuatoriano de Derecho Ambiental, Quito Ecuador, 2010.

SUPERINTENDENCIA DE COMPAÑÍAS, "Tendencias del Mercado de Valores", Boletín no. 56, 2008. Consulted 2 March 2015, available at: $<\mathrm{http}: / / w w w$. supercias.gov.ec $>$.

URQUIZU CAVALLÉ, A., "El fideicomiso en Ecuador”, in Urquizu Cavallé, A. (dir.), El Fideicomiso en Latinoamérica. Integración jurídico-financiera, Marcial Pons 
(Madrid, Barcelona, Buenos Aires), 2010.

— "Análisis jurídico de la tributación de las rentas de los beneficios empresariales obtenidos en Ecuador", in URQUIZU CAVALLÉ, A. (dir.), La tributación de los beneficios empresariales obtenidos en América Latina, Marcial Pons, Madrid, 2012.

UNITED NATIONS DEVELOPMENT PROGRAM (UNDP) MULTI-PARTNER TRUSTFUND OFFICE. National MDTF Factsheet - Ecuador Yasuní Capital Window.

Consulted 2 March 2015, available at: $<$ http://mptf.undp.org/factsheet/fund/3EYC0/es $>$.

VILLCA POZO, M.: "El fideicomiso en Bolivia", in Urquizu Cavallé, A. (dir.), El Fideicomiso en Latinoamérica. Integración jurídico-financiera, Marcial Pons (Madrid, Barcelona, Buenos Aires), 2010.

- _ "El fideicomiso en Perú", in Urquizu Cavallé, A. (dir.), El Fideicomiso en Latinoamérica. Integración jurídico-financiera, Marcial Pons (Madrid, Barcelona, Buenos Aires), 2010.

YÁNEZ, I.: Why did the Yasuni-ITT initiative fail? Dossier. Power dynamics and natural resources. Expert Opinion. The Broker. Connecting worlds of knowledge. Consulted 5 May 2015, available at: <http://www.thebrokeronline.eu/Blogs/Powerdynamics-and-natural-resources/Why-did-the-Yasuni-ITT-initiative-fail>. 